\title{
Effect of Salinity-Changing Rates on Filtration Activity of Mussels from Two Sites within the Baltic Mytilus Hybrid Zone: The Brackish Great Belt (Denmark) and the Low Saline Central Baltic Sea
}

\author{
Hans Ulrik Riisgård*, Magali Mulot, Lucia Merino, Daniel Pleissner \\ Marine Biological Research Centre, University of Southern Denmark, Kerteminde, Denmark \\ Email: hur@biology.sdu.dk
}

Received 13 December 2013; revised 17 January 2014; accepted 9 February 2014

Copyright (C) 2014 by authors and Scientific Research Publishing Inc.

This work is licensed under the Creative Commons Attribution International License (CC BY). http://creativecommons.org/licenses/by/4.0/

(c) (i) Open Access

\begin{abstract}
Mussels from two sites within the Baltic mussel (Mytilus edulis $\times$ M. trossulus) hybrid zone were used in a comparative study on the effects of salinity-changing rates on filtration activity. The acute effect of varying salinity-changing rates was found to be similar in M. edulis from the brackish Great Belt and in M. trossulus from the low saline Central Baltic Sea, and the relationships could be described by linear regression lines through 0.0 indicating that the acute effect of deteriorating conditions at decreasing salinities is the opposite as for improving conditions when the salinity is subsequently increased. Further, both $M$. edulis and $M$. trossulus acclimatized to 20 psu reacted to an acute salinity change to 6.5 psu by immediately closing their valves whereupon the filtration rate gradually increased during the following days, but only $M$. trossulus had completely acclimatized to 6.5 psu within 5 days which may be explained by different genotypes of $M$. edulis and $M$. trossulus which probably reflected an evolutionary adaptation of the latter to survive in the stable low-salinity Baltic Sea.
\end{abstract}

\section{Keywords}

Blue Mussels; Mytilus edulis; Mytilus trossulus; Acute Salinity Effects; Acclimatization; Filtration Rates

\footnotetext{
${ }^{*}$ Corresponding author.
}

How to cite this paper: Riisgård, H.U., et al. (2014) Effect of Salinity-Changing Rates on Filtration Activity of Mussels from Two Sites within the Baltic Mytilus Hybrid Zone: The Brackish Great Belt (Denmark) and the Low Saline Central Baltic Sea. Open Journal of Marine Science, 4, 101-109. http://dx.doi.org/10.4236/ojms.2014.42011 


\section{Introduction}

Permanent low salinity as well as frequency, amplitude and rate of salinity changes may influence feeding, growth, early development and survival of mussels and other filter-feeding bivalves [1]-[13].

The euryhaline blue mussel (Mytilus edulis L.) is able to live in both stable low salinity water areas and in estuaries with extreme salinity fluctuations. The immediate reaction of $M$. edulis to acute exposure to strongly reduced salinity water is closure of the valves whereby high saline water is retained within the mantle cavity [14], but also closure of the exhalant siphon and cessation of through-flowing water that prevents the gills and body against exposure to low-saline water may be part of the behavioral response to reduced salinity [1] [15]. The effect of salinity changes on the filtration rate of $M$. edulis from the brackish Great Belt (Denmark), which is one of the Danish Straits connecting the North Sea with the Baltic Sea and characterized by frequently changing salinities, was recently studied by Riisgård et al. [16]. Thus, at salinities between 30 and 10 psu the filtration rate was not much influenced, but at 5 psu the filtration rate remained reduced during 3 weeks (see Figure 1 in Riisgård et al. [16]). However, when mussels from 6.5 psu in the Central Baltic Sea (Äskö, 70 km south of Stockholm) were initially acclimatized to 20 psu and subsequently re-exposed to 6.5 psu this initially caused a drastic reduction in the filtration rate, but the previous high filtration rate, comparable to that of Great Belt mussels, was regained after 1 - 2 days at 6.5 psu (see Figure 3 in Riisgård et al. [16]). This difference in ability to fully acclimatize the filtration rate may be explained by different genotypes of the experimental mussels collected at the two sites within the Baltic Mytilus hybrid zone that is characterized by multilocus clines between $M$. edulis and $M$. trossulus [17]-[23].

The effect of changing salinity on the filtration rate of mussels from Great Belt has recently been studied by Pleissner et al. [24] who found that the filtration rate was unaffected by decreasing salinity down to about 10 psu, but below this threshold the mussels begun to close their valves and reduce the filtration rate. When the salinity was subsequently increased, the normal filtration rate was soon after restored, and Pleissner et al. [24] concluded that the filtration activity is strongly influenced by the salinity-changing rate: the faster the salinity is either reduced or increased, the more pronounced is the change in the filtration rate.

In the present work, we have performed a comparative study on the effects of salinity-changing rates on the filtration activity of Mytilus edulis from Great Belt and on M. trossulus from the low saline Central Baltic Sea where the blue mussel is dwarfed [25]-[27].

\section{Materials and Methods}

\subsection{Salinity-Changing Rate Experiment}

The newly developed fluorometer controlled apparatus (FCA) constructed by Pleissner et al. [24] was used in the present study with a few modifications in order to establish filtration-rate measurements on mussels at controlled salinity-changing rates. The FCA maintains a constant defined algal concentration in an aquarium with mussels by adding concentrated algal suspension to replace the amount of algal cells removed. The volume of algal suspension added to the aquarium is determined by the filtration activity of the mussels and wash out of algal cells with outflow from the aquarium. Water from the aquarium with mussels is continuously recycled through a tube to the fluorometer containing a flow-through cuvette what enables a continuous measurement of the algal concentration. If the algal concentration is below a defined level a peristaltic pump starts to pump a suspension of concentrated algae from a bottle (algal stock) into the aquarium to keep the algal concentration constant. The filtration rates were estimated by means of the equation [24]:

$$
F=\frac{P_{a} \times C_{s}-\left(P_{a}+P_{d}\right) \times C_{a}}{C_{a} \times n}
$$

where $P_{a}=$ pumping rate of algal-dosing pump; $P_{d}=$ pumping rate of pump adding distilled water or salt water (see below; $P_{a}+P_{d}=$ outflow from aquarium), calculated from the total volume of well-mixed algal stock suspension added to the aquarium per unit of time, $n=$ number of mussels, $C_{s}=$ algal concentration in stock suspension, $C_{a}=$ algal concentration in well-mixed aquarium. The FCA was used to keep a constant concentration of algae in the aquarium (5000 Rhodomonas salina cells $\cdot \mathrm{ml}^{-1}$ ) during the salinity-changing experiments. In order to cross-check the filtration rates estimated from the FCA, the algal dosing-pump was temporary stopped and the filtration rate was then measured as the volume of water cleared of algal cells per unit of time (i.e. 
clearance rate). The reduction in the number of cells as a function of time was followed by taking water samples $(10 \mathrm{ml})$ from the aquarium at fixed time intervals of $5 \mathrm{~min}$ and measuring the particle concentration with an electronic particle counter (Elzone 5380). Because the about $6.3 \mu \mathrm{m}$ algal cells are $100 \%$ efficiently retained by the gills of the mussels (i.e. cell diameter larger than $4 \mu \mathrm{m}$ [28]) the measured clearance rate equals the filtration rate (= pumping rate). The clearance rate $\left(F_{C R}\right)$ was determined from the exponential decrease in algal concentration as a function of time using the formula (e.g. Riisgård et al. [29]):

$$
F_{C R}=\frac{V \times b}{n}
$$

where $b=$ slope of regression line in a semi-ln plot for the reduction in algal concentration with time, $V=$ water volume in aquarium, $n=$ number of mussels. A control experiment without mussels showed that sedimentation of algal cells was insignificant, and in all cases good agreement was observed between $F_{C R}$ and $F$ measured by means of the FCA.

In order to measure the effect of decreasing and subsequent increasing of salinity on the filtration rate of mussels an adjustable peristaltic pump was activated to supply the mussel aquarium with distilled water from a tank resulting in decreasing salinity with a certain constant rate $\left(\Delta S\right.$, psu $\left.\mathrm{h}^{-1}\right)$ in the aquarium down to about 2 psu whereupon the dosing pump was changed to supply the aquarium with 18 psu bio-filtered seawater from another tank. To predict the decrease of the salinity in the aquarium, the following equation was used:

$$
S_{t+x}=\frac{S_{t} \times V_{a}+20 \times x \times P_{a}}{V_{a}+P_{a} \times x+P_{d} \times x}
$$

where $S_{t}=$ salinity in the aquarium at the time $t, S_{t+x}=$ salinity in the aquarium $x$ min after $t, V_{a}=$ volume of water in the aquarium, $P_{a}=$ pumping rate of dosing pump supplying 20 psu algal culture to the aquarium, $P_{d}=$ pumping rate of dosing pump adding distilled water. The estimated salinity values obtained with Equation (3) were cross-checked with actual measurements (YSI 30) made during the period with decreasing salinity.

For subsequently increasing the salinity in mussel aquarium the dosing pump was switched to supply the mussel aquarium with 18 psu seawater from a tank resulting in increasing salinity with a certain rate $(\Delta S$, $\mathrm{psu} \cdot \mathrm{h}^{-1}$ ). To predict the increase of the salinity in the aquarium, the following equation was used:

$$
S_{t+x}=\frac{S_{t} \times V_{a}+20 \times x \times P_{a}+18 \times x \times P_{d}}{V_{a}+P_{a} \times x+P_{d} \times x}
$$

where $P_{d}=$ pumping rate of dosing pump supplying the mussel aquarium with 18 psu seawater. The salinitychanging rates were calculated for the laps of time during which the mussels responded to changes in salinity. During this laps of time, the decrease (or increase) of the salinity was considered near linear so that the dilution rate (or strengthening rate) was given by the slope of a straight line for salinity versus time in the experimental period where the filtration rate was affected. The mussel shell opening degree (SOD), defined as the distance between the shells just below the exhalant siphon aperture [29], was measured manually from a digital photo by using a ruler placed on the glass wall of the experimental aquarium close to the mussel.

Blue mussels, Mytilus edulis, were collected in Great Belt, Denmark, and kept in the nearby Marine Biological Research Centre (SDU) in aerated flow-through tanks supplied with seawater (18 $\pm 1 \mathrm{psu})$ until the experiments were performed. Two size groups of mussels were used: one group mussels $(n=5)$ collected 12 June 2013 with a mean shell length of $48 \pm 2 \mathrm{~mm}$ (Group: "M. edulis, $48 \mathrm{~mm}$ ”), and a group mussels $(n=10)$ collected 8 July 2013 with a mean shell length of $20 \pm 2 \mathrm{~mm}$ (Group: “M. edulis, $20 \mathrm{~mm}$ ”). Further, in one series of experiments a group of dwarfed mussels, M. trossulus (collected 23 May 2013) from the low saline (6.5 psu) Central Baltic Sea near Åland (Finland) were used, and here a group of 10 mussels with a mean shell length of $20 \pm 2 \mathrm{~mm}$ (Group: “ $M$. trossulus, $20 \mathrm{~mm}$ ”) were kept through-flowing seawater (18 $\pm 1 \mathrm{psu}$ ) until they were transferred to the experimental aquarium after 3 weeks of acclimation. All experiments were performed at $13^{\circ} \mathrm{C}$ $-15^{\circ} \mathrm{C}$.

\subsection{Acclimatization of Filtration Rate to Changed Salinity}

In order to study the ability of mussels to acclimatize the filtration rate to changed salinity, one group $(n=5)$ of Mytilus edulis collected 10 August 2013 in Great Belt (shell length $16.8 \pm 0.7 \mathrm{~mm}$ ) and another group $(n=5)$ of 
M. trossulus collected 23 May 2013 in the Central Baltic Sea near Åland (16.5 $\pm 1.1 \mathrm{~mm}$ ) were initially acclimatized in the laboratory to $18 \pm 1 \mathrm{psu}$ at $14^{\circ} \mathrm{C}$ for 3 weeks in aquaria with through-flowing natural seawater. The mean individual filtration rate of the two groups of mussels was measured in separate aquaria $(V=2000 \mathrm{ml})$ with air-mixed seawater by means of the clearance method using Equation (2). After initial measurement of the filtration rate at $20 \mathrm{psu}$, the mussels were subsequently exposed to $6.5 \mathrm{psu}$ seawater from the collecting site near Åland for about one week before the salinity was again changed to 20 psu. Seawater with required salinity was obtained by adjusting the natural seawater with distilled water or salt (Red Sea Marine Salt).

\subsection{Cultivation of Algae}

The algae used was the flagellate Rhodomonas salina (about $6.3 \mu \mathrm{m}$ diameter), grown in repeated batch cultures at $20^{\circ} \mathrm{C}$ in $10 \mathrm{l}$ glass bottles containing $9 \mathrm{l}$ of seawater (20 psu) enriched with $\mathrm{f} / 2$-medium. Cultures were continuously illuminated by light tubes and aeration and mixing were ensured by injection of compressed air. Every day $3 \mathrm{l}$ of algal suspension was withdrawn and replaced by new medium.

\subsection{Statistical Analysis}

The influence of mussel size for sensitivity of filtration activity to varying salinity-changing rates was evaluated by statistically testing the effect of shell length of mussels on experimentally measured $\Delta F$, after controlling for effects of $\Delta S$, by using analysis of covariance (ANCOVA) in SPSS 12.

\section{Results}

Figure 1 shows an example of a salinity-changing experiment performed with a group of $48 \mathrm{~mm}$ Mytilus edulis. In this case the $\Delta F$-values were found to be $-9.73 \mathrm{ml} \cdot \mathrm{min}^{-1} \cdot \mathrm{h}^{-1}$ for decreasing salinity $\left(\Delta S=-0.86 \mathrm{psu} \cdot \mathrm{h}^{-1}\right)$ and $12.67 \mathrm{ml} \cdot \mathrm{min}^{-1} \cdot \mathrm{h}^{-1}$ for increasing salinity $\left(\Delta S=0.98 \mathrm{psu} \cdot \mathrm{h}^{-1}\right)$. The results from 7 similar experiments with varying salinity-changing rates are shown in Figure 2 along with two other experiments performed with $20 \mathrm{~mm}$ shell length M. edulis from Great Belt and M. trossulus from the Central Baltic Sea, respectively. In all cases, the relationships can be described by linear regression lines through 0.0 which indicate that the acute effect on filtration rate to salinity-changing rates for deteriorating conditions at decreasing salinities is the opposite as for improving conditions when the salinity is subsequently being increased. The slope of the regression line for the individual size group of mussels is an expression for the sensitivity of the mussels, but slopes of regression lines for $\Delta F$-values versus $\Delta S$-values for mussels of different size (and thus different levels of filtration rate) cannot be directly compared. Statistical tests show that there is no difference in effect of $\Delta S$ on $\Delta F$ between $20 \mathrm{~mm} M$. edulis and $M$. trossulus mussels from the two locations $\left(\mathrm{F}_{1 ; 14}=0.595 ; \mathrm{p}=0.453\right)$, between 20 and $48 \mathrm{~mm} M$. edulis from Great Belt $\left(\mathrm{F}_{1 ; 19}=0.954 ; \mathrm{p}=0.341\right)$, and further no difference $\left(\mathrm{F}_{1 ; 20}=0.668 ; \mathrm{p}=0.423\right)$ between 20 $\mathrm{mm}$ M. trossulus and $48 \mathrm{~mm}$ M. edulis.

Figure 3 shows the effect of salinity changes on filtration rates of Mytilus edulis collected in Great Belt and in $M$. trossulus collected the Central Baltic Sea. In both cases the mussels reacted to the acute salinity changes by immediately closing their valves, thus reducing the filtration rate by some $90 \%$, whereupon the filtration rate gradually increased during the following days. It is notable that $M$. trossulus had completely acclimatized to 6.5 psu within 5 days whereas M. edulis had only partly acclimatized within 7 days. The ability of the two groups of mussels to recover (i.e. filtration rate fully acclimated) from exposure to 6.5 psu when re-exposed to 20 psu was one day for the Central Baltic Sea mussels and two days for the Great Belt mussels. It may be concluded that only $M$. trossulus from the low saline Central Baltic Sea are able to fully acclimatize to a sudden, strongly reduced salinity (from 20 to 6.5 psu) within 5 days (Figure 3), and further, these mussels are able to fully recover within only one day when re-exposed to increased salinity (20 psu), whereas M. edulis from Great Belt need two days. But the acute effect of varying salinity-changing rates is similar in the two groups of mussels (Figure 2) and this indicate that the ability of dwarfed Central Baltic Sea mussels to re-acclimatize and filter at maximum rates at very low salinities may be a unique ability that is not correlated with a reduced sensibility of the filtration rate to acute changes in salinity compared to Great Belt mussels.

\section{Discussion}

The present results may be compared to recent preliminary data presented by Pleissner et al. ([24], Figure 9 

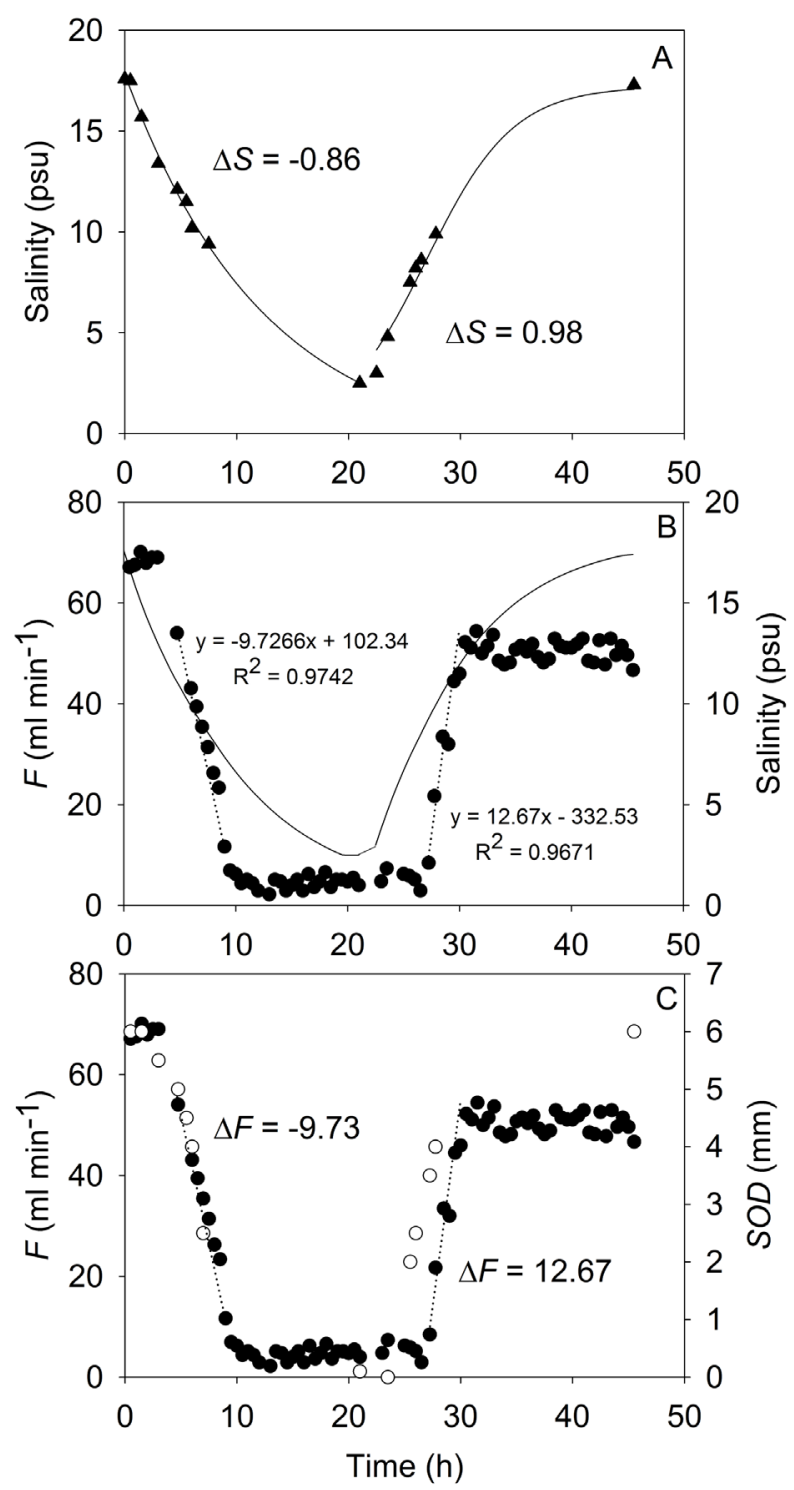

Figure 1. (A) Actually measured salinity (closed triangles) and estimated decreasing and increasing salinities during an experiment using Equations (3) and (4) respectively; (B) Measured mean filtration rates of a group $(n=5)$ of $48 \mathrm{~mm}$ shell length mussels (Mytilus edulis) using the FCA during an experiment with initially decreasing salinity followed by a period with increasing salinity (inserted curve). The equations for regression lines for decreasing and increasing filtration rates are shown; (C) Mean filtration rates (closed symbol) and shell opening degree (SOD, open symbol) during a salinity-changing experiment. The negative $\left(\Delta F, \mathrm{ml} \mathrm{min}^{-1} \cdot \mathrm{h}^{-1}\right)$ and positive $(\Delta F)$ filtration-changing rates are indicated (i.e. slopes of regression lines for shell closing/opening periods indicated in figure B).

therein) who found that the filtration-changing rate $(\Delta F)$ of $29 \mathrm{~mm}$ Mytilus edulis from Great Belt was strongly influenced by the salinity-changing rate $(\Delta S)$ : "the faster the salinity was either reduced or increased, the more the change was pronounced in the filtration rate”. In the present study we have shown that this relationship can be described by a linear regression line through 0.0 .

The ability of blue mussels from the Central Baltic Sea to fully acclimatize their filtration rate to a suddenly 

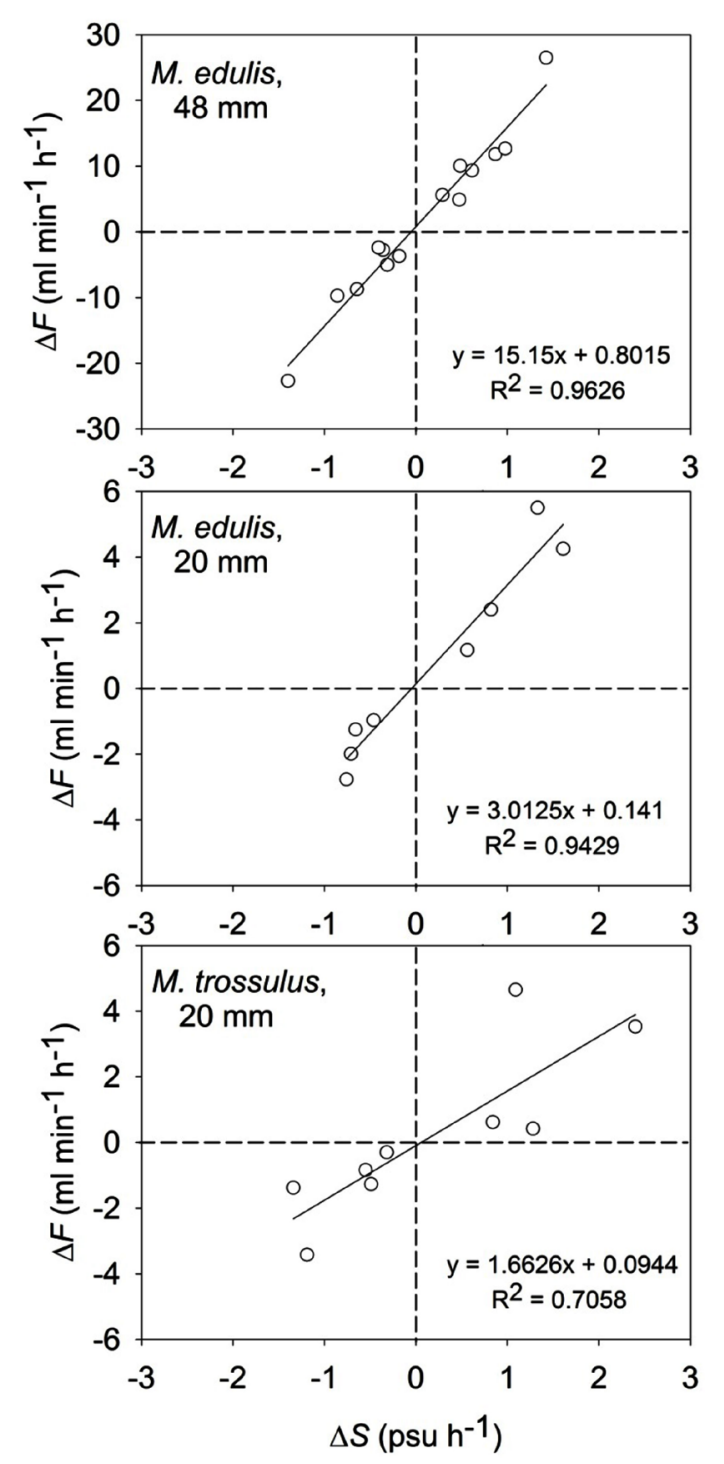

Figure 2. Filtration-changing rate $(\Delta F)$ of mussels as a function of salinity-changing rate $(\Delta S)$ in experiments with two groups of mussels from Great Belt (Mytilus edulis: $48 \mathrm{~mm}, 20 \mathrm{~mm}$ ) and one group of mussels from the coastal waters of Åland in the Central Baltic Sea ( $M$. trossulus: $20 \mathrm{~mm}$ ).

reduced salinity from 20 to 6.5 psu within 5 days (Figure 3) is in good agreement with the recent findings by Riisgård et al. ([16], Figure 3 therein) who suggested that the ease of Baltic Sea mussels to adjust back and forth between 6.5 and 20 psu may be explained by different genotypes of the experimental mussels collected at two sites within the Baltic mussel (Mytilus edulis $\times$ Mytilus trossulus) hybrid zone [5] [7] [13]-[17]. Kautsky et al. [5] found that the growth rate of M. edulis is much lower in the stable low-salinity Baltic Sea than in the North Sea (28 psu), and reciprocally transplanted mussels were found to grow at rates similar to those of native mussels, and further, the survival of Baltic Sea mussels was very high in contrast to mortality over $90 \%$ among North Sea mussels transferred to the Baltic Sea, and therefore Kautsky et al. [5] suggested that the different survival had mainly "genetic causes".

The relevance of the present study for actual salinity changes in Great Belt may be evaluated by comparing laboratory data with frequency and amplitude of salinity-changing rates measured above the permanent halocline in the northern Great Belt in the period 2000-2010 (Riisgård et al. [11], Table 1 therein). The mean salinity in 


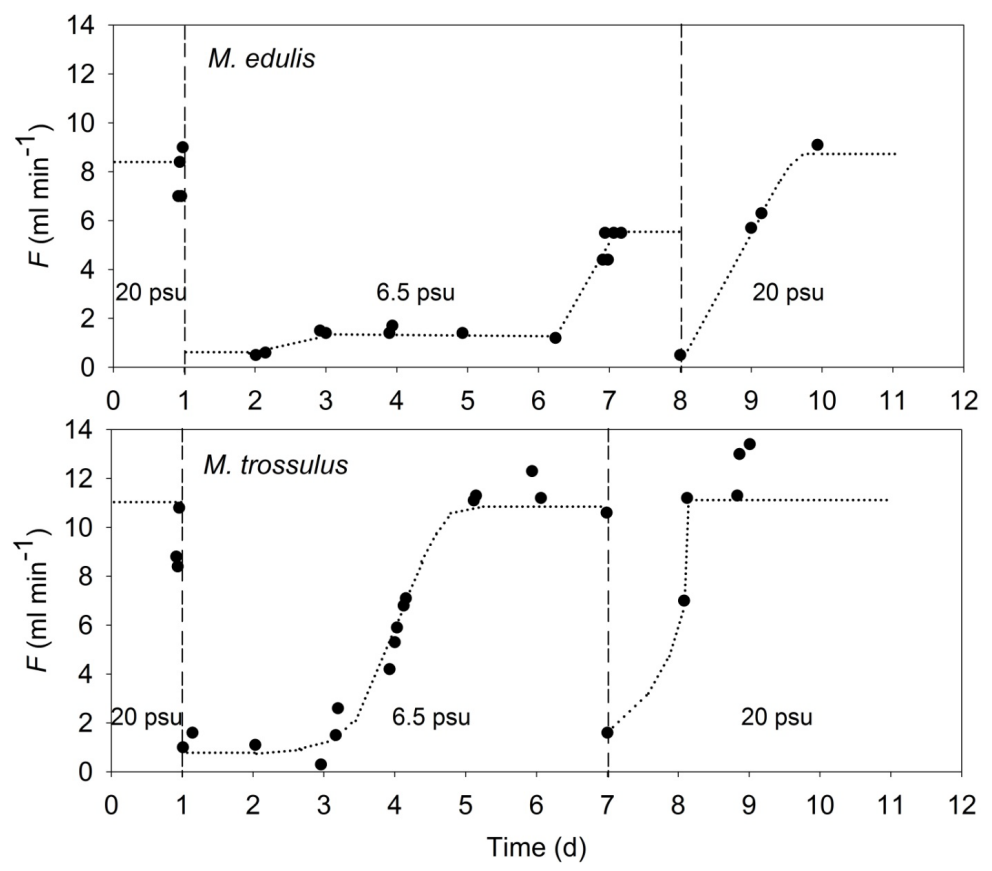

Figure 3. Mean individual filtration rates $(F)$ of mussels collected in Great Belt and locally adapted to 20 psu (Mytilus edulis), and mussels collected in the Central Baltic Sea (near Åland) and locally adapted to 6.5 psu (M. trossulus). The mussels were in both filtration-rate experiments initially acclimatized for 3 weeks to 20 psu and then acutely exposed to 6.5 psu on Day 1 (left vertical dash line) before again exposed to 20 psu after 7 and 8 days, respectively (right vertical dash line). Dotted lines fitted by eye indicate the behavior of $F$ during the experiments.

Great Belt is about 17 psu, major salinity changes of about 8.5 psu take place with an annual frequency of about 10 , a mean duration time of $21 \mathrm{~d}$, and with a mean salinity-changing rate of $0.4 \mathrm{psu} \cdot \mathrm{d}^{-1}=0.017 \mathrm{psu} \cdot \mathrm{h}^{-1}$, which may be compared to the $\Delta S$-values used in the present study (Figure 2). Here, the lowest salinity-changing rate was $\Delta S=0.18 \mathrm{psu} \cdot \mathrm{h}^{-1}$, or about 10 times higher than the mean changing rate in Great Belt, but it remains to be shown if salinity-changing rates of that order may have any notable acute effects on the filtration rate, or if the acclimatization ability of the mussels (e.g. [30] [31]) may prevent, or blur such effects.

It may be concluded that the acute effect of varying salinity-changing rates is similar in Mytilus edulis from Great Belt and M. trossulus from the Central Baltic Sea, i.e. the changes in filtration rates are linearly proportional to the acute changes in salinity (Figure 2), and further, the ability of M. trossulus to fully re-acclimatize to very low salinities (Figure 3 ) is likely to be genetically determined, reflecting an evolutionary adaptation to survive in the stable low salinity waters of the Baltic Sea.

\section{Acknowledgements}

Thanks are due to Mads van Deurs for collection of mussels and transport of seawater from the Central Baltic Sea to Kerteminde, and to Kim Lundgreen for technical support and for participation in the preliminary experiments.

\section{References}

[1] Davenport, J. (1979) The Isolation Response of Mussels (Mytilus edulis L.) Exposed to Falling Seawater Concentrations. Journal of the Marine Biological Association of the United Kingdom, 59, 123-132. http://dx.doi.org/10.1017/S0025315400046221

[2] Almada-Villela, P.C. (1984) The Effects of Reduced Salinity on the Shell Growth of Small Mytilus edulis. Journal of the Marine Biological Association of the United Kingdom, 64, 71-182. http://dx.doi.org/10.1017/S0025315400059713 
[3] Gruffydd, L.L.D., Huxley, R. and Crisp, D.J. (1984) The Reduction in Growth of Mytilus edulis in Fluctuating Salinity Regimes Measured Using Laser Diffraction Patterns and the Exaggeration of This Effect by Using Tap Water as the Diluting Medium. Journal of the Marine Biological Association of the United Kingdom, 64, 401-409. http://dx.doi.org/10.1017/S0025315400030071

[4] Essink, K. and Bos, A.H. (1985) Growth of Three Bivalve Molluscs Transplanted along the Axis of the Ems Estuary. Netherlands Journal of Sea Research, 19, 45-51. http://dx.doi.org/10.1016/0077-7579(85)90042-0

[5] Kautsky, N., Johannesson, K. and Tedengren, M. (1990) Genotypic and Phenotypic Differences between Baltic and North Sea Populations of Mytilus edulis Evaluated through Reciprocal Transplantations. I. Growth and Morphology. Marine Ecology Progress Series, 59, 203-210. http://dx.doi.org/10.3354/meps059203

[6] Tedengren, M., André, C., Johannesson, K. and Kautsky, N. (1990) Genotypic and Phenotypic Differences between Baltic and North Sea Populations of Mytilus edulis Evaluated through Reciprocal Transplantations. III. Physiology. Marine Ecology Progress Series, 59, 221-227. http://dx.doi.org/10.3354/meps059221

[7] Westerbom, M., Kilpi, M. and Mustonen, O. (2002) Blue Mussels, Mytilus edulis, at the Edge of the Range: Population Structure, Growth and Biomass along a Salinity Gradient in the North-Eastern Baltic Sea. Marine Biology, 140, 991999. http://dx.doi.org/10.1007/s00227-001-0765-6

[8] Marsden, I.D. (2004) Effects of Reduced Salinity and Seston Availability on Growth of the New Zealand Little-Neck Clam Austrovenus stutchburi. Marine Ecology Progress Series, 266, 157-171. http://dx.doi.org/10.3354/meps266157

[9] Hamer, B., Jaksic, Z., Pavicic-Hamer, D., Peric, L., Medakovic, D., Ivankovic, D., Pavicic, J., Zilberg, C., Schröder, H.C., Müller, W.E.G., Smodlaka, N. and Batel, R. (2008) Effect of Hypoosmotic Stress by Low Salinity Acclimation of Mediterranean Mussels Mytilus galloprovincialis on Biological Parameters Used for Pollution Assessment. Aquatic Toxicology, 89, 137-151. http://dx.doi.org/10.1016/j.aquatox.2008.06.015

[10] Qiu, J.-W., Tremblay, R. and Bourget, E. (2002) Ontogenetic Changes in Hyposaline Tolerance in the Mussels Mytilus edulis and M. trossulus: Implications for Distribution. Marine Ecology Progress Series, 228, 143-152. http://dx.doi.org/10.3354/meps228143

[11] Riisgård, H.U., Bøttiger, L. and Pleissner, D. (2012) Effect of Salinity on Growth of Mussels, Mytilus edulis, with Special Reference to Great Belt (Denmark). Open Journal of Marine Science, 2, 167-176. http://dx.doi.org/10.4236/ojms.2012.24020

[12] Hiebenthal, C., Philipp, E.E.R., Eisenhauer, A. and Wahl, M. (2012) Interactive Effects of Temperature and Salinity on shell Formation and General Condition in Baltic Sea Mytilus edulis and Arctica islandica. Aquatic Biology, 14, 289298. http://dx.doi.org/10.3354/ab00405

[13] McFarland, K., Donaghy, L. and Volety, A.K. (2013) Effect of Acute Salinity Changes on Hemolymph Osmolality and Clearance Rate of the Non-Native Mussel, Perna viridis, and the Native Oyster, Crassostrea virginica, in Southwest Florida. Aquatic Invasions, 8, 299-310. http://dx.doi.org/10.3391/ai.2013.8.3.06

[14] Costa, C.J. and Pritchard, A.W. (1978) The Response of Mytilus edulis to Short Duration Hypoosmotic Stress. Comparative Biochemistry and Physiology, 61A, 149-155. http://dx.doi.org/10.1016/0300-9629(78)90292-X

[15] Davenport, J. (1979) Is Mytilus edilis a Short Term Osmoregulator? Comparative Biochemistry and Physiology, 64A, 91-95. http://dx.doi.org/10.1016/0300-9629(79)90436-5

[16] Riisgård, H.U., Lüskow, F., Pleissner, D., Lundgreen, K. and López, M.A.P. (2013) Effect of Salinity on Filtration Rates of Mussels Mytilus edulis with Special Emphasis on Dwarfed Mussels from the Low-Saline Central Baltic Sea. Helgoland Marine Research, 67, 591-598. http://dx.doi.org/10.1007/s10152-013-0347-2

[17] Theisen, B.F. (1978) Allozyme Clines and Evidence of Strong Selection in Three Loci in Mytilus edulis L. (Bivalva) from Danish Waters. Ophelia, 17, 135-142. http://dx.doi.org/10.1080/00785326.1978.10425477

[18] H.-P. Bulnheim and E. Gosling (1988) Population Genetic Structure of Mussels from the Baltic Sea. Helgoländer Meeresuntersuchungen, 42, 113-129. http://dx.doi.org/10.1007/BF02364207

[19] Johannesson, K., Kautsky, N. and Tedengren, M. (1990) Genotypic and Phenotypic Differences between Baltic and North Sea Populations of Mytilus edulis Evaluated through Reciprocal Transplantations. II. Genetic Variation. Marine Ecology Progress Series, 59, 211-219. http://dx.doi.org/10.3354/meps059211

[20] Riginos, C. and Cunningham, C.W. (2005) Local Adaptation and Species Segregation in Two Mussel (Mytilus edulis $\times$ Mytilus trossulus) Hybrid Zones. Molecular Ecology, 14, 381-400. http://dx.doi.org/10.1111/j.1365-294X.2004.02379.x

[21] Zbawicka, M., Burzynski, A. and Wenne, R. (2007) Complete Sequences of Mitochondrial Genomes from the Baltic Mussel Mytilus trossulus. Gene, 406, 191-198. http://dx.doi.org/10.1016/j.gene.2007.10.003

[22] Stuckas, H., Stoof, K., Quesada, H. and Tiedemann, R. (2009) Evolutionary Implications of Discordant Clines across the Baltic Mytilus Hybrid Zone (Mytilus edulis and Mytilus trossulus). Heredity, 103, 146-156. 
http://dx.doi.org/10.1038/hdy.2009.37

[23] Väinölä, R. and Strelkov, P. (2011) Mytilus trossulus in Northern Europe. Marine Biology, 158, 817-833. http://dx.doi.org/10.1007/s00227-010-1609-z

[24] Pleissner, D., Lundgreen, K., Lüskow, F. and Riisgård, H.U. (2013) Fluorometer Controlled Apparatus Designed for Long-Term Algal-Feeding Experiments and Environmental Effect Studies with Mussels. Journal of Marine Biology, 2013, Article ID: 401961. http://dx.doi.org/10.1155/2013/401961

[25] Kautsky, N. (1982) Growth and Size Structure in a Baltic Mytilus edulis Population. Marine Biology, 68, 117-133. http://dx.doi.org/10.1007/BF00397599

[26] Tedengren, M. and Kautsky, N. (1986) Comparative Study of the Physiology and Its Probable Effect on Size in Blue Mussels (Mytilus edulis L.) from the North Sea and the Northern Baltic Proper. Ophelia, 25, 147-155. http://dx.doi.org/10.1080/00785326.1986.10429746

[27] Vuorinen, I., Antsulevich, A.E. and Maximovich, N.V. (2002) Spatial Distribution and Growth of the Common Mussel Mytilus edulis L. in the Archipelago of SW-Finland, Northern Baltic Sea. Boreal Environment Research, 7, 41-52.

[28] Møhlenberg, F. and Riisgård, H.U. (1978) Efficiency of Particle Retention in 13 Species of Suspension-Feeding Bivalves. Ophelia, 17, 139-246. http://dx.doi.org/10.1080/00785326.1978.10425487

[29] Riisgård, H.U., Jørgensen, B.H., Lundgreen, K., Storti, F., Walther, J.H., Meyer, K.E. and Larsen, P.S. (2011) The Exhalant Jet of Mussels Mytilus edulis. Marine Ecology Progress Series, 437, 147-164. http://dx.doi.org/10.3354/meps09268

[30] Neufeld, D.S. and Wright, S.H. (1996) Response of Cell Volume in Mytilus Gill to Acute Salinity Change. The Journal of Experimental Biology, 199, 473-484.

[31] Sadok, S., Uglow, R.F. and Haswell, S.J. (1997) Haemolymph and Mantle Fluid Ammonia and Ninhydrin Positive Substances Variations in Salinity-Challenged Mussels (Mytilus edulis L.). Journal of Experimental Marine Biology and Ecology, 212, 195-212. http://dx.doi.org/10.1016/S0022-0981(96)02732-3 